\author{
УДК 373.3.091.33-027.22:796 \\ doi: 10.15330/fcult.33.40-51
}

Тетяна Кравченко

\title{
ОПТИМІЗАЦЯ ФІЗИЧНОЇ ПІДГОТОВЛЕНОСТІ УЧНІВ МОЛОДШОГО ШКІЛЬНОГО ВІКУ ЗАСОБАМИ РУХЛИВИХ ІГОР В УМОВАХ НОВОЇ УКРАЇНСЬКОї ШКОЛИ
}

\begin{abstract}
Мета охарактеризувати та експериментально перевірити вплив уроків з елементами розроблених рухливих ігор та естафет на рівень розвитку фізичної підготовленості учнів початкової школи. Методи й організація дослідження. Нами був проведений педагогічний експеримент протягом 20172019 н.р, на базі Вербівського навчально-виховного комплексу “Загальноосвітня школа I-II ступенів дошкільний навчальний заклад” Висоцької сільської ради, Дубровицького району, Рівненської області. У дослідженнях взяли участь 65 учнів. Отримані результати. Експериментально доведено щзо застосування рухливих ігор та естафет,під час динамічних перерв в урочний час сприяли підвищенню рівня фізичної підготовленості у учнів експериментальної групи. Висновки. Відповідно до результатів дослідження можемо констатувати, щуо одним з найбільш ефективних засобів вирішення проблеми розвитку фізичної підготовленості в молодшому шкільному віці є рухливі ігри.
\end{abstract}

Ключові слова: типова освітня програма, молодші школярі, рухлива ігри, естафети, динамічні перерви.

The process of optimizing physical fitness, strengthening the physical and mental health of children of primary school age requires special attention and detailed study. After all, the physical fitness of modern youth is deteriorating every year, and the incidence of children in all regions of Ukraine is significantly increasing. The goal is to characterize and experimentally test the effect of lessons with elements of developed mobile games and relays on the level of development of physical fitness of elementary school students. Methods and organization of research. We conducted a pedagogical experiment during February-May with students of the control group, that is, the 2017-2018 academic year, and September-January of the 2018-2019 academic year, with students of the experimental group on the basis of the Verbovsky teaching and educational complex "Secondary school I-III steps - preschool educational institution" Vysotsk village council, Dubrovitsk district, Rivne region. The study involved 31 students of the experimental group (EG) of 1-4 grades and 34 students of the control group (CG). The pupils of the two groups were divided into groups: 6-7 years old (1-2 class) and 8-9 years old (3-4 class), which were evaluated separately. Used such research methods as theoretical analysis and synthesis of scientific and methodological literature; pedagogical methods (pedagogical experiment; pedagogical observation; pedagogical testing); anthropometry; methods of mathematical statistics. Results. Analysis of data indicators anthropometric data, where the average length and body weight of boys and girls grades 1-4 control (CG) and experimental (EG) groups is within the age norm. The chest circumference in boys and girls correspond to the level of development. The physical fitness of students in the experimental and control groups has become an experimentally proven engine for the use of mobile games and relays, and dynamic interruptions in the time period for the development of physical fitness in students of the experimental group. Therefore, the positive effect of the introduction of 1-4 grades of outdoor games into practical forms of study has been experimentally proved. Findings. The new program provides for a wider use of mobile games, as well as the ability of each teacher to independently choose mobile games in accordance with the objectives of the lesson. According to the results of the study, we can state that one of the most effective means of solving the problem of developing physical fitness in primary school age is outdoor games.

Key words: Typical educational program, younger students, outdoor games, relay races, dynamic changes.

Постановка проблеми й аналіз результатів останніх досліджень.

Актуальність. У Законі України “Про загальну середню освіту” одним із основних завдань, є оптимізація фізичної підготовленості учнів, та зміцнення їх фізичного та психічного здоров'я. Але особливої уваги та детального вивчення потребує процес оптимізації фізичної підготовленості, зміцнення фізичного та психічного здоров'я дітей молодшого шкільного віку. Адже фізична підготовленість сучасної молоді погіршується 3 кожним роком, а захворюваність дітей на території всіх областей України значно зростає особливо це яскраво проявилося за останні роки. Саме тому, вивчення та до- 
слідження даної проблеми дасть нам змогу підвищити рівня фізичної підготовленості, зміцнити фізичне та психологічне здоров'я молодших школярів.

Проблемі фізичної підготовки та вікового розвитку фізичних якостей школярів присвячені роботи Шияна Б.М., Москаленко Н. В.,Презлята Г.В., Худолій О.М. та інших фахівців у галузі фізичної культури, які стверджують, що рухова підготовленість $\epsilon$ важливим компонентом здоров'я учнів, а ії поліпшення - однією з головних завдань фізичного виховання в школі $[9,18,19]$.

У роботах Вільчковського Е.С., Круцевич Т.Ю. та інших, проблема фізичного виховання, фізичної підготовленості, та здоров'я дітей посідає досить вагоме місце, і досліджена досить детально. Автори зазначають, позитивний вплив на організм, що зростають оздоровчі програми, які спрямовані на підвищення рівня фізичного стану молодших школярів [3, 7].

У відповідності до Державного стандарту початкової освіти (постанова КМ України від 21 лютого 2018 року) в умовах становлення Нової української школи актуалізується проблема формування соціальної та інших ключових компетентностей, стійкої мотивації до занять фізичною культурою і спортом для забезпечення гармонійного фізичного розвитку, підвищення функціональних можливостей організму, вдосконалення життєво необхідних рухових умінь та навичок [18].

Розвиток фізичної підготовленості у молодшому шкільному віці тісно пов'язана 3 використанням рухливих ігор, оскільки до їх складу входять основні природні рухи людини, які виконуються у різних поєднаннях і комбінаціях $[14,26]$.

Крім того рухливі ігри мають яскраву емоційну забарвленість, слугують засобом набуття дитиною соціального досвіду.

Мета дослідження - Охарактеризувати та експериментально перевірити вплив уроків з елементами розроблених рухливих ігор та естафет на рівень розвитку фізичної підготовленості учнів початкової школи.

Методи й організація дослідження. Нами був проведений педагогічний експеримент протягом лютого-травня з учнями контрольної групи, тобто 2017-2018 н.р, та вересня-січня 2018-2019 н.р. з учнями експериментальної групи, на базі Вербівського навчально-виховного комплексу “Загальноосвітня школа I-II ступенів - дошкільний навчальний заклад” Висоцької сільської ради, Дубровицького району, Рівненської області.

Сутність нашого експерименту полягає в оптимізації фізичної підготовленості молодших школярів у процесі фізичного виховання. У дослідженнях взяли участь 31 учень експериметальної групи (ЕГ) 1-4 класів та 34 учні контрольної групи (КГ). Учні двох груп були поділені на групи: 6-7 років (1-2 клас) та 8-9 років (3-4 клас), що оцінювались окремо.

Підчас проведення експериментального дослідження нами використовувалися такі методи дослідження: теоретичний аналіз та узагальнення науково-методичної літератури; педагогічні методи (педагогічний експеримент; педагогічне спостереження; педагогічне тестування); антропометрія; методи математичної статистики.

Результати і дискусія. Одним з характерних проявів погіршення здоров'я школярів $\epsilon$ значне погіршення фізичної підготовленості та зменшення фізичної активності дітей $[17,20,22]$. Як стверджує Т.Ю. Круцевич цю проблему можна пояснити низьким рівнем ефективності уроків фізичної культури і фізкультурно-оздоровчих занять, які базувалися на застарілих підходах дозування фізичних навантажень [10]. Неодноразово у дослідженнях вчених Круцевич Т.Ю., Шиян Б.М., Худолій О.М. стверджувалось, що існуюча система навчання дітей на уроках фізичної культури не відповідала за змістом, об’єму, інтенсивності навантаження дитячому організму, а головне, не враховувала 
індивідуальних особливостей школярів $[7,11,24,23,25]$. Зважаючи на проблеми які висвітлювали вчені відбулися зміни в навчальному процесі закладів середньої освіти.

Верховна Рада України 5 вересня 2017 року ухвалила новий закон "Про освіту", відповідно до якого діти, що пішли до школи у 2018 н.р. навчатимуться 12 років. Це потребує переходу до використання нових типових програм фізкультурної освітньої галузі, які прививали б практичні навички використання знань та вмінь які отримують в школі та у повсякденному житті. Закон дозволяє вчителям працювати за розробленими ними освітніми програмами відповідно до Державного стандарту початкової освіти [18] або використовувати типові освітні програми Шиян Р.Б чи Савченко О.Я.

Типова освітня програма фізкультурної освітньої галузі під керівництвом Шиян Р.Б. охоплює три змістові лінії. Метою цієї галузі для загальної середньої освіти є формування в учнів стійкої мотивації до занять фізичною культурою і спортом та життєво необхідних рухових умінь і навичок для збереження власного здоров'я, розширення функціональних можливостей організму. Відповідно до мети, складений ряд завдань, на основі яких розроблені змістові лінії, що мають обов'язкові та очікуванні результати навчання для учнів 1-2 класу, що не поділені на роки вивчення, як у Савченко О.Я.

Змістові лінії за Р.Б. Шиян та їх характеристика:

1) “Базова рухова активність” - охоплює види діяльності, що спрямовані на формування життєво необхідних рухових умінь і навичок, включає різновиди дитячого фітнесу, що на наш погляд, є продуктивним засобом розвитку особистості учня та спиряє підвищенню фізичної підготовленості;

2) "Ігрова та змагальна діяльність учнів (рухливі ігри та естафети)" задовольняє потребу в руховій активності та сприяє формуванню комунікативних здібностей, фізичній підготовленості і обов'язкове виконання правил чесної гри;

3) “Турбота про стан здоров'я та безпеку” спрямована на формування свідомого ставлення до власного здоров'я та вмінь безпечної поведінки в процесі фізкультурної діяльності, тобто учні навчаються контролювати власне самопочуття, розрізняти ознаки втоми, вплив навантаження на їх організм.

Виконання завдань даної галузі допускає відхід від жорсткої регламентації занять, підвищення їхньої емоційної насиченості, максимальної різноманітності форм, методів та засобів фізичного виховання, широкого використання інноваційних технологій фізичного виховання задля розв'язання завдань фізкультурної освітньої галузі.

Змістові лінії типової освітної програми з фізичної культури під керівництвом Савченко О.Я. та їх характеристика:

1) "Рухова діяльність" передбачає формування в молодших школярів уявлення про фізичну культуру як про сукупність різноманітних фізичних вправ, способів рухової та ігрової діяльності, формування в молодших школярів умінь та навичок володіння способами рухової діяльності, формування правильної постави й профілактику плоскостопості і т.д.

2) “Ігрова та змагальна діяльність” виховує у молодших школярів ініціативність, активність, відповідальність у процесі рухливих і спортивних ігор за спрощеними правилами, навчає здобувати чесну перемогу та з гідністю сприймати поразку, формує в молодших школярів уміння і навички використання естафет і т.д. Метою навчання $\epsilon$ всебічний фізичний розвиток особистості учня засобами фізичної культури та ігрової діяльності, формування ключових компетентностей, ціннісного ставлення до фізичної культури, спорту, фізкультурно-оздоровчих занять та виховання фізично загартованих і патріотично налаштованих громадян України.

Тож можемо підсумувати, що завдання типових програм Савченко О.Я. та Шиян Р.Б. є схожими за своїми змістом та метою. Відмінною є кількість змістових 
ліній за Шияном Р.Б. три, а Савченко О.Я. пропонує лише дві, а також за її програмою передбачене навчання 3 плавання (за наявності обладнання у 33СО), та різновиди дитячого фітнесу, що включені в програму Шиян Р. Б. У відповідності до Державного стандарту початкової освіти (постанова Кабінету Міністрів України від 21.02.2018p.) здобувач освіти повинен вміти керуватися правилами безпечної і чесної гри, боротися, вигравати і програвати, усвідомлювати значення фізичних вправ для здоров'я, емоційного задоволення, гартування характеру, самовираження та соціальної взаємодії, що реалізується через типові освітні програми Савченко О.Я. та Шиян Р.Б. Типові освітні програми наведені вище не містять нормативних показників, як начальна програма для 1-4 класів. Додатки вчитель використовує за своїм бажанням (використання бальної оцінки в системі педагогічного контролю фізичної підготовленості школярів; умови виконання вправ для визначення резервних можливостей учнів; орієнтовні показники динаміки змін розвитку фізичних якостей молодших школярів; показники рухової компетентності учнів та фізичної підготовленості за період навчання 3 першого по четвертий клас.

Проблема оптимізації фізичної підготовленості школярів потребує систематичного вдосконалення. Для цього доцільно використовувати найрізноманітніші форми фізкультурно-оздоровчої роботи в урочний та позаурочний час, виховувати в дітей потребу в щоденних заняттях фізичними вправами $[3,5,13]$, тому ми вирішили використовувати рухливі ігри та естафети.

Відповідно на основі проекту Державного стандарту початкової загальної освіти, що грунтується на 6 принципах, один 3 яких є “здоров'я” - формування здорового способу життя і створення умов для фізичного й психоемоційного розвитку, що $є$ надзвичайно важливим для дітей молодшого шкільного віку [15], адже проблема фізичного розвитку та фізичної підготовленості дітей шкільного віку набула особливої актуальності в наш час..

Враховуючі зміни до Державного стандарту початкової освіти [18] можна стверджувати, що типові освітні програми фізкультурної освітньої галузі нової української школи є рушієм для розвитку рухової активності та фізичної підготовленості дітей, адже висуваються значні вимоги до розвитку рухової діяльності, формування компетентностей, які використовуватимуться у житті здобувачами освіти, що в подальшому позитивно впливатиме на сучасних молодших школярів та всіх учнів нової української школи. Тому при розробці календарно-тематичного планування уроків фізичної культури, відповідно до типової освітньої програми розробленої під керівництвом Р.Б. Шиян від 21 лютого 2018 р. №87 м. Київ, ми розробили рухливі ігри та естафети "Перенесення тарілок на голові" “Збір урожаю”, “Стрибучість найвищого", “Злови мене”, які ми активно використовували при вивченні змістової лінії "Ігрова та змагальна діяльність” [17].

Можемо зазначити, що саме молодший шкільний вік є найбільш сприятливим часом для використання рухливих ігор у процесі виховання. Рухливі ігри різної спрямованості є дуже ефективним засобом комплексного вдосконалення фізичних якостей та фізичної підготовленості [6].

Нами був проведений педагогічний експеримент протягом лютого-травня 3 учнями контрольної групи, тобто 2017-2018 н.р, та вересня-січня 2018-2019 н.р. 3 учнями експериментальної групи, на базі Вербівського навчально-виховного комплексу “Загальноосвітня школа I-II ступенів - дошкільний навчальний заклад” Висоцької сільської ради, Дубровицького району, Рівненської області.

Сутність нашого експерименту полягає в оптимізація фізичної підготовленості молодших школярів в процесі фізичного виховання на основі сучасних здоров'язбе- 
режувальних технологій початкової освіти. У дослідженнях взяли участь 31 учень експериметальної групи (ЕГ) 1-4 класів та 34 учні контрольної групи (КГ). Учні двох груп були поділені на групи: 6-7 років (1-2 клас) та 8-9 років (3-4 клас), що оцінювались окремо.

Та були використані такі тести: Частота рухів визначалась за результатами стрибків двома ногами на місці з опорою за 20 секунд. Швидкісно-силові якості визначали за результатом стрибка у довжину з місця. Силові якості оцінювались за показниками кількості присідань для дівчат та хлопців за 20 секунд. Дослідження гнучкості проводили за допомогою тесту “нахил тулуба вперед з положення сидячи". Координація визначалась за допомогою “Човниковий” біг 4х9 м (сек.) експериментальної та контрольної груп. Силова витривалість вимірювалась тестом “піднімання тулуба в сід за 30 секунд". Та антропометричні показники.

На констатувальному етапі дослідження було проаналізовано та узагальнено вітчизняні літературні джерела з питань методології, теорії і практики виховання учнів молодшого шкільного віку, у тому числі і методичні посібники, наукові статті з даної проблематики; дослідження досвіду використання динамічних перерв, рухливих ігор та естафет для оптимізації фізичної підготовленості молодших школярів, зокрема, на основі Державного стандарту початкової освіти; визначено рівень фізичного розвитку дітей та рівень фізичної підготовленості.

Формувальний етап дослідження передбачав проведення педагогічного експерименту, взявши за основу динамічні перерви та рухливі ігри й естафети для дітей молодшого шкільного віку. Для проведення дослідної роботи було створено експериметальну групу (31 учень), з яких 6-7 років хлопчики $(\mathrm{n}=8)$, дівчаток $(\mathrm{n}=6), 8-9$ років - хлопчиків $(\mathrm{n}=10)$, дівчаток $-(\mathrm{n}=7)$. До контрольної групи відносилось 34 учні, 3 них 6-7 років: хлопці $-(\mathrm{n}=9)$, дівчатка $-(\mathrm{n}=6) ; 8-9$ років: хлопці $(\mathrm{n}=11)$, дівчатка $(\mathrm{n}=8)$. Особливістю фізкультурно-оздоровчої роботи для дітей експериментальної групи було використання динамічні перерви, а до уроків фізичної культури додавали розроблені рухливі ігри: “Перенесення тарілок на голові”, “Збір урожаю”, “Стрибучість найвищого”, “Злови мене”. Уроки проводились за освітньою програмою розробленою під керівництвом Р.Б. Шияна, відповідно до Державного стандарту початкової освіти на основі якої було складене календарно-тематичне планування уроків фізичної культури на II семестр. А уроки у контрольній групі відбувались відповідно до навчальної програми з фізичної культури для учнів $1-4$ класів.

В ході проведення формувального експерименту перевірено вплив динамічних перерв та рухливих ігор на оптимізацію фізичної підготовленості учнів 1-4 класів експериментальної груп.

Після закінчення експерименту було зроблено обробку та аналіз отриманих результатів, проведено порівняння результатів тестування дітей молодшого шкільного віку, а саме учнів експериментальної групи (1-4 класу) що навчалися за типовою освітньою програмою фізкультурної галузі Нової української школи до якої буди додані розроблені рухливі ігри та естафети та учні контрольної групи (1-4 класу) що навчалися у відповідності до навчальної програми з фізичної культури для учнів 1-4 класів. Математична обробка даних, узагальнення результатів дослідження, формулювання висновків та оформлення роботи.

Отже середньостатистичні значення морфологічних параметрів фізичного розвитку учнів молодшого шкільного віку експериментальної та контрольної груп дають уявлення про стан фізичного розвитку дітей та його відповідність віковим нормам у ЕГ (табл. 1), та КГ у (табл. 2). 
Кравченко Тетяна. Оптимізація фізичної підготовленості учнів молодшого шкільного віку ...

Табличя 1

Показники фізичного розвитку хлопчиків та дівчаток молодшого шкільного віку ЕГ (6-7 та 8-9 років)

\begin{tabular}{|c|c|c|c|c|}
\hline \multirow[t]{2}{*}{ Показники } & \multicolumn{2}{|c|}{ Хлопчики 6-7 років } & \multicolumn{2}{|c|}{ Дівчатка 6-7 років } \\
\hline & $\overline{\boldsymbol{x}}$ & $\mathbf{S}$ & $\overline{\boldsymbol{x}}$ & $\mathbf{S}$ \\
\hline Довжина тіла, см & 122,5 & 2,81 & 118,8 & 1,88 \\
\hline Маса тіла, кг & 23,6 & 5,14 & 22,4 & 2,81 \\
\hline ОГК, см & 65,5 & 2,58 & 63,2 & 1,42 \\
\hline \multirow{2}{*}{ Показники } & \multicolumn{2}{|c|}{ Хлопчики 8-9 років } & \multicolumn{2}{|c|}{ Дівчатка 8-9 років } \\
\hline & $\overline{\boldsymbol{x}}$ & $\mathbf{S}$ & $\overline{\boldsymbol{x}}$ & $\mathbf{S}$ \\
\hline Довжина тіла, см & 134,2 & 2,81 & 129,8 & 2,35 \\
\hline Маса тіла, кг & 28,9 & 5,35 & 29,4 & 5,60 \\
\hline ОГК, см & 73,5 & 4,37 & 68,6 & 5,97 \\
\hline
\end{tabular}

Середній показник довжини та маси тіла хлопчиків і дівчаток 6-7 та 8-9 років експериментальної групи знаходиться у межах вікової норми. Показники окружності грудної клітки у хлопчиків та дівчаток відповідають середньому рівню розвитку.

Дослідження фізичного розвитку хлопчиків 6-7 та 8-9 років експериментальної групи свідчить, що досліджувані є однорідними за показниками довжини тіла $(\mathrm{S}=2,81)$, маси тіла 6-7 $(\mathrm{S}=5,14), 8-9(\mathrm{~S}=5,35)$, окружності грудної клітки 6-7 $(\mathrm{S}=2,58)$, 8-9 $(\mathrm{S}=4,37)$. Вивчення фізичного розвитку дівчаток свідчить, що досліджувані є однорідними за показниками довжини тіла 6-7 $(\mathrm{S}=1,88), 8-9(\mathrm{~S}=2,35)$, окружності грудної клітки 6-7 $(\mathrm{S}=1,42), 8-9(\mathrm{~S}=5,79)$, маси тіла 6-7 $(\mathrm{S}=2,81), 8-9(\mathrm{~S}=5,60)$.

Табличя 2

Показники фізичного розвитку хлопчиків та дівчаток молодшого шкільного віку КГ (6-7 та 8-9 років)

\begin{tabular}{|c|c|c|c|c|}
\hline \multirow[t]{2}{*}{ Показники } & \multicolumn{2}{|c|}{ Хлопчики 6-7 років } & \multicolumn{2}{|c|}{ Дівчатка6-7 років } \\
\hline & $\bar{x}$ & $\mathbf{S}$ & $\overline{\boldsymbol{x}}$ & $\mathbf{S}$ \\
\hline Довжина тіла, см & 124,3 & 3,13 & 122,5 & 2,16 \\
\hline Маса тіла, кг & 22,2 & 5,63 & 20,3 & 3,43 \\
\hline ОГК, см & 63,5 & 3,23 & 61,2 & 2,27 \\
\hline \multirow{2}{*}{ Показники } & \multicolumn{2}{|c|}{ Хлопчики 8-9 років } & \multicolumn{2}{|c|}{ Дівчатка 8-9 років } \\
\hline & $\bar{x}$ & $\mathbf{S}$ & $\bar{x}$ & $\mathbf{S}$ \\
\hline Довжина тіла, см & 130,3 & 3,32 & 128,4 & 2,86 \\
\hline Маса тіла, кг & 26,7 & 5,47 & 25,3 & 6,86 \\
\hline ОГК, см & 69,4 & 5,23 & 67,5 & 6,24 \\
\hline
\end{tabular}

Середній показник довжини та маси тіла хлопчиків і дівчаток контрольної групи 6-7 та 8-9 років знаходиться у межах вікової норми. Показники окружності грудної клітки у хлопчиків та дівчаток відповідають середньому рівню розвитку.

Дослідження фізичного розвитку хлопчиків 6-7 та 8-9 років контрольної групи свідчить, що досліджувані $є$ однорідними за показниками довжини тіла 6-7 років $(S=3,13), 8-9$ років $(S=3,32)$ маси тіла $6-7$ років $(S=5,63), 8-9$ років $(S=5,47)$, окружності 
грудної клітки 6-7 років $(\mathrm{S}=3,23), 8-9$ років $(\mathrm{S}=5,23)$. Вивчення фізичного розвитку дівчаток свідчить, що досліджувані є однорідними за показниками довжини тіла 6-7 років $(\mathrm{S}=2,16), 8-9$ років $(\mathrm{S}=2,86)$ окружності грудної клітки 6-7 років $(\mathrm{S}=2,27), 8-9(\mathrm{~S}=6,86)$, років маси тіла 6-7 років $(S=3,43), 8-9$ років $(S=6,24)$.

Середній показник довжини та маси тіла хлопчиків і дівчаток 1-4 класів контрольної (КГ) та експериментальної (ЕГ) груп знаходиться у межах вікової норми. Показники окружності грудної клітки у хлопчиків та дівчаток відповідають рівню розвитку.

Фізична підготовленість випробуваних визначалася за результатами педагогічного тестування, яке констатувало рівень прояву таких якостей: частота рухів, швидкісно-силові якості, сила, гнучкість, координація, силова витривалість. Середні показники фізичної підготовленості обстежених хлопчиків та дівчаток 6-7 та 8-9 років експериментальної та контрольної груп наведені в (табл. 3), (табл. 4), (табл. 5), (табл. 6).

Таблиия 3

Показники фізичної підготовленості хлопчиків $(\mathrm{n}=8)$ та дівчаток $(\mathrm{n}=6) 6-7$ років ЕГ

\begin{tabular}{|l|c|c|c|c|}
\hline \multicolumn{1}{|c|}{ Показники } & \multicolumn{2}{|c|}{ Хлопчики } & \multicolumn{2}{c|}{ Дівчатка } \\
\cline { 2 - 5 } & $\overline{\boldsymbol{x}}$ & $\mathbf{S}$ & $\overline{\boldsymbol{x}}$ & $\mathbf{S}$ \\
\hline Присідання за 20 секунд & 30,25 & 5,06 & 29,75 & 8,60 \\
\hline $\begin{array}{l}\text { Стрибки на двох ногах на місці } \\
\text { опорою об стіл за 20 секунд, рази }\end{array}$ & 20 & 4,72 & 22,8 & 3,31 \\
\hline $\begin{array}{l}\text { Нахил тулуба вперед із положення } \\
\text { сидячи, см }\end{array}$ & 5,5 & 1,88 & 6,1 & 1,62 \\
\hline “Човниковий” біг 4х9 м (сек.) & 12,93 & 1,13 & 13,84 & 1,17 \\
\hline Стрибок у довжину з місця, см & 118,5 & 15,07 & 104,8 & 13,72 \\
\hline Піднімання тулуба в сід за 30 с, рази & 16,6 & 1,61 & 20,2 & 1,24 \\
\hline
\end{tabular}

Наведені дані у хлопчиків свідчать про однорідність показників у таких вправах як: “присідання за 20 секунд” ( $\mathrm{S}=5,06)$, “стрибки на двох ногах на місці з опорою об стіл за 20 секунд" (S=4,72). Середня ступінь варіювання показників у вправах "нахил тулуба вперед із положення сидячи", “піднімання тулуба в сід за 30 секунд" "Човниковий” біг 4x9 м (сек) ( $\mathrm{S}=1,88, \mathrm{~S}=1,61$ і $\mathrm{S}=1,13$ відповідно). Значне розсіювання показників спостерігається у вправі “стрибок у довжину з місця” (S=15,07).

Дослідження фізичної підготовленості дівчаток свідчить про однорідність показників у таких вправах як:“стрибки на двох ногах на місці з опорою об стіл за 20 секунд” $(\mathrm{S}=3,31)$. Середня ступінь варіювання показників у вправах "нахил тулуба вперед із положення сидячи", “піднімання тулуба в сід за 30 секунд" "Човниковий” біг 4х9 м (сек) ( $\mathrm{S}=1,62$ і $\mathrm{S}=1,24 \mathrm{~S}=1,17$ відповідно). Найбільші коливання показників спостерігається у вправі “стрибок у довжину з місця" $(S=13,72)$, “присідання за 20 секунд” $(S=8,60)$.

Показники частоти рухів, швидкісно-силових якостей, гнучкості, сили хлопчиків та дівчат знаходяться на високому рівні. Середні показники силової витривалості хлопців - на низькому, а дівчат - на середньому рівнях.

Отже, більшість показників розвитку фізичних якостей хлопчиків і дівчаток знаходиться на середньому та високому рівнях. Високий рівень спостерігається частіше, ніж низький та середній. 
Кравченко Тетяна. Оптимізація фізичної підготовленості учнів молодшого шкільного віку ...

Таблиия 4

Показники фізичної підготовленості хлопчиків(n=10) та дівчаток $(n=7)$ 8-9 років ЕГ

\begin{tabular}{|l|c|c|c|c|}
\hline \multicolumn{2}{|c|}{ Показники } & \multicolumn{2}{|c|}{ Хлопчики } & \multicolumn{2}{c|}{ Дівчатка } \\
\cline { 2 - 5 } & $\overline{\boldsymbol{x}}$ & $\mathbf{S}$ & $\overline{\boldsymbol{x}}$ & $\mathbf{S}$ \\
\hline Присідання за 20 секунд & 21,75 & 1,92 & 24,2 & 3,41 \\
\hline $\begin{array}{l}\text { Стрибки на двох ногах на місці } \\
\text { опорою об стіл 3а 20 секунд, рази }\end{array}$ & 40 & 3,67 & 38,1 & 6,73 \\
\hline $\begin{array}{l}\text { Нахил тулуба вперед із положення } \\
\text { сидячи, см }\end{array}$ & 11 & 2,80 & 11,4 & 2,82 \\
\hline “Човниковий” біг 4х9 м (сек.) & 11,93 & 1,05 & 12,84 & 1,14 \\
\hline Стрибок у довжину з місця, см & 143,8 & 10,54 & 129,9 & 13,51 \\
\hline Піднімання тулуба в сід за 30 с, рази & 21 & 2,12 & 19,8 & 5,08 \\
\hline
\end{tabular}

Однорідність даних фізичної підготовленості хлопчиків проявляється у вправі “стрибки на двох ногах на місці з опорою об стіл за 20 секунд” $(S=3,67)$. Середня ступінь варіювання показників у вправах "нахил тулуба вперед із положення сидячи", “піднімання тулуба в сід за 30 секунд" "Човниковий” біг 4х9 м (c) $(\mathrm{S}=2,80$ і $\mathrm{S}=2,12 \mathrm{~S}=1,05$ відповідно), "присідання за 20 секунд" $(\mathrm{S}=1,92)$. Значне розсіювання показників спостерігається у вправі “стрибок у довжину з місця” $(\mathrm{S}=10,54)$.

Дослідження фізичної підготовленості дівчаток свідчить про однорідність показників у таких вправах як:“стрибки на двох ногах на місці 3 опорою об стіл за 20 секунд", “піднімання тулуба в сід за 30 секунд”( $\mathrm{S}=6,73$ і $\mathrm{S}=5,08)$. Середня ступінь варіювання показників у вправах “нахил тулуба вперед із положення сидячи", “присідання за 20 секунд" “Човниковий” біг 4x9 м (сек) ( $\mathrm{S}=2,82$ і $\mathrm{S}=3,41 \mathrm{~S}=1,14)$. Найбільші коливання показників спостерігається у вправі “стрибок у довжину з місця” $(S=13,51)$.

Середні показники витривалості хлопців та дівчат знаходяться на високому рівні, так само як і показники частоти рухів, гнучкості, координаціï, швидкісно-силових якостей. Показники сили знаходяться на середньому рівні. Отже, використання рухливих ігор та естафет, динамічних перерв з учнями експериментальної групи справило позитивний ефект на розвиток фізичної підготовленості.

Табличя 5

Показники фізичної підготовленості хлопчиків $(\mathrm{n}=8)$ та дівчаток (n=6) 6-7 років КГ

\begin{tabular}{|c|c|c|c|c|}
\hline \multirow{2}{*}{ Показники } & \multicolumn{2}{|c|}{ Хлопчики } & \multicolumn{2}{|c|}{ Дівчатка } \\
\hline & $\overline{\boldsymbol{x}}$ & $\mathbf{S}$ & $\overline{\boldsymbol{x}}$ & $\bar{S}$ \\
\hline Присідання за 20 секунд & 27,5 & 6,70 & 25,5 & 9,84 \\
\hline $\begin{array}{l}\text { Стрибки на двох ногах на місці } 3 \\
\text { опорою об стіл за } 20 \text { секунд, рази }\end{array}$ & 19,6 & 5,10 & 21,3 & 3,53 \\
\hline $\begin{array}{l}\text { Нахил тулуба вперед із положення } \\
\text { сидячи, см }\end{array}$ & 5,2 & 1,88 & 3,1 & 1,35 \\
\hline “Човниковий” біг 4x9 м (сек.) & 13,13 & 1,15 & 13,96 & 1,19 \\
\hline Стрибок у довжину з місця, см & 116,7 & 15,88 & 102,2 & 14,3 \\
\hline Піднімання тулуба в сід за 30 с, рази & 15,8 & 1,72 & 20,3 & 1,44 \\
\hline
\end{tabular}


Наведені дані у хлопчиків свідчать про однорідність показників у таких вправах як:“стрибки на двох ногах на місці з опорою об стіл за 20 секунд” $(\mathrm{S}=5,10)$. Середня ступінь варіювання показників у вправах "нахил тулуба вперед із положення сидячи”, "піднімання тулуба в сід за 30 секунд" "Човниковий” біг 4x9 м (сек) (S=1,88 і S=1,72 $\mathrm{S}=1,15$ відповідно). Значне розсіювання показників спостерігається у вправі “стрибок у довжину з місця" ( $S=15,88)$, “присідання за 20 секунд” $(S=6,70)$.

Дослідження фізичної підготовленості дівчаток свідчить про однорідність показників у таких вправах як: “стрибки на двох ногах на місці з опорою об стіл за 20 секунд" ( $\mathrm{S}=3,53)$. Середня ступінь варіювання показників у вправах "нахил тулуба вперед із положення сидячи", “піднімання тулуба в сід за 30 секунд" "Човниковий” біг 4x9 м (сек) ( $\mathrm{S}=1,35$ і $\mathrm{S}=1,44 \mathrm{~S}=1,19$ відповідно). Найбільші коливання показників спостерігається у вправі “стрибок у довжину з місця" $(\mathrm{S}=14,3)$, “присідання за 20 секунд” $(\mathrm{S}=9,84)$.

Показники частоти рухів, швидкісно-силових якостей, сили хлопчиків та дівчат знаходяться на високому рівні, гнучкості (у хлопців - високому, дівчат - середньому) рівнях. Середні показники силової витривалості хлопців - на низькому, а дівчат - на середньому рівнях.

Отже, більшість показників розвитку фізичних якостей хлопчиків і дівчаток знаходиться на середньому рівні, тому він спостерігається частіше, ніж низький та високий.

Показники фізичної підготовленості хлопчиків (n=10)

Таблиия 6

та дівчаток $(n=7)$ 8-9 років КГ

\begin{tabular}{|c|c|c|c|c|}
\hline \multirow{2}{*}{ Показники } & \multicolumn{2}{|c|}{ Хлопчики } & \multicolumn{2}{|c|}{ Дівчатка } \\
\hline & $\bar{x}$ & $\mathbf{S}$ & $\overline{\boldsymbol{x}}$ & $\mathbf{S}$ \\
\hline Присідання за 20 секунд & 20,1 & 1,92 & 22,9 & 4,83 \\
\hline $\begin{array}{l}\text { Стрибки на двох ногах на місці } 3 \\
\text { опорою об стіл за } 20 \text { секунд, рази }\end{array}$ & 35 & 6,40 & 34,5 & 7,50 \\
\hline $\begin{array}{l}\text { Нахил тулуба вперед із положення } \\
\text { сидячи, см }\end{array}$ & 10 & 4,30 & 11,2 & 2,97 \\
\hline “Човниковий” біг 4x9 м (сек.) & 11,53 & 0,95 & 11,84 & 1,05 \\
\hline $\begin{array}{l}\text { Стрибок } \\
\text { у довжину з місця, см }\end{array}$ & 134,5 & 12,45 & 127,4 & 14,29 \\
\hline Піднімання тулуба в сід за 30 с, рази & 19 & 2,44 & 18,5 & 5,99 \\
\hline
\end{tabular}

Однорідність даних хлопчиків проявляється у вправі “стрибки на двох ногах на місці з опорою об стіл за 20 секунд” $(S=6,40)$, “нахил тулуба вперед 3 положення сидячи" $(\mathrm{S}=4,30)$. Середня ступінь варіювання показників у вправі “піднімання тулуба в сід за 30 секунд” ( $S=2,44)$, “присідання за 20 секунд” $(S=1,92)$. Значне розсіювання показників спостерігається у вправі “стрибок у довжину з місця" ( $\mathrm{S}=12,45)$. На високому рівні знаходиться рівень розвитку координації “Човниковий” біг 4х9 м (сек.). $(\mathrm{S}=0,95)$

Дослідження фізичної підготовленості дівчаток свідчить про однорідність показників у таких вправах як: “присідання за 20 секунд” $(S=4,83)$ “піднімання тулуба в сід за 30 секунд” ( $S=5,99)$. Середня ступінь варіювання показників у вправах “нахил тулуба вперед із положення сидячи" (S=2,97). Найбільші коливання показників спостерігається у вправі “стрибок у довжину з місця" $(\mathrm{S}=14,29)$, “стрибки на двох ногах на місці з опорою об стіл за 20 секунд” $(S=7,50)$. Рівень розвитку координації “Човниковий” біг $4 \mathrm{x} 9$ м (сек). на високому рівні у всіх учнів. $(S=0,95)$ 
Середні показники витривалості хлопців та дівчат знаходяться на високому рівні, так само як і показники частоти рухів, гнучкості, координації, швидкісно-силових якостей. Показники сили хлопчиків та дівчаток знаходяться на середньому рівні.

Отже, проаналізувавши дані показників фізичної підготовленості учнів експериментальної та контрольної групи можна побачити вищий рівень розвитку якостей у учнів експериментальної групи. Позитивний ефект проведення рухливих ігор та динамічних перерв можна вважати доведеним.

\section{Висновки.}

Зробивши теоретичний аналіз і узагальнення психолого-педагогічної літератури можемо зробити висновок, що метою фізкультурної освітньої галузі в умовах нової української школи $є$ формування ключових компетентностей, стійкої мотивації до занять фізичною культурою і спортом для забезпечення гармонійного фізичного та психологічного розвитку. Нова програма передбачає більш широке застосування рухливих ігор.

Аналіз показників антропометричних даних, де середній показник довжини та маси тіла хлопчиків і дівчаток 1-4 класів контрольної (КГ) та експериментальної (ЕГ) груп знаходиться у межах вікової норми. Показники окружності грудної клітки у хлопчиків та дівчаток відповідають рівню розвитку. Фізична підготовленість учнів експериментальної та контрольної групи засвідчує щозастосування рухливих ігор та естафет, під час динамічних перерв в урочний час $\epsilon$ ефективними засобами підвищення фізичної підготовленості школярів експериментальної групи. Тому позитивний ефект впровадження в урочні форми занять учнів 1-4 класів рухливих ігор експериментально доведено.

1. Борисова ЮЮ. Диференційований підхід у фізичному вихованні школярів на основі використання комп'ютерних технологій : автореф. дис. на здоб. наук. ступеня канд. наук з фіз. вих. і спорту : спец. 24.00.02 “Фізична культура, фізичне виховання різних груп населення”. Дніпропетровськ, 2009. 20 с.

2. Виленская ТЕ. Физическое воспитание детей младшего школьного возраста : учеб. пособие. Ростов н/Д : Феникс, 2006. 256 с.

3. Вільчковський ЕС. Теорія і методика фізичного виховання дітей молодшого шкільного віку. Львів: ВНТЛ, 2008. $336 \mathrm{c.}$

4. Волков ЛВ. Молодший шкільний вік: виховна спрямованість занять фізичною культурою і спортом : навч. посіб. К.: Освіта України, 2007. 152 с.

5. Динамічні перерви. 1-2 класи. упоряд. В. П. Порощук. Х.: Вид. група “Основа”, 2018.221, [3] с. (Серія “Нова українська школа").

6. Єдинак Г. Плахтій П, Яценюк Ю. Фізична культура в школі: молодому спеціалісту : навч.-метод. посіб. Кам'янець-Поділ., 2000. 305 с.

7. Круцевич ТЮ. Безверхня ГВ. Рекреація у фізичній культурі різних груп населення : навчальний посібник. К.: Олімпійська література, 2010. 248 с.

8. Круцевич ТЮ. Петровский ВВ. Физическое воспитание как социальное явление. Наука в олимпийском спорте. 2001; № 3:3-15.

9. Москаленко НВ. Фізичне виховання молодших школярів : монографія. Д : Вид-во “Інновація”, 2007. $252 \mathrm{c}$.

10. Мудрик СБ. Рухливі ігри на уроках фізичної культури. Луцьк, 2008. 89 с.

11. Нова українська школа: порадник для вчителя / Під заг. ред. Н. М. Бібі. К.: ТОВ “Видавничий дім "Плеяди", 2017: 24-25.

12. Островець ТО. Формування мотивації до занять фізичною культурою шляхом застосування різних засобів навчання. Посібник для вчителів фізичної культури, здобувачів освіти 33СО, 2018. $21 \mathrm{c.}$

13. Презлята ГВ. Народні і забави у формуванні фізичного гарту / ГВ.Презлята//Вісник Прикарпатського університету.Фізична культура.Івано-Франківськ, 2006; Вип.2: 57-62

14. Про затвердження Державного стандарту початкової освіти : Постанова Кабінету Міністрів України від 21 лютого 2018 р. № 87.

15. Про схвалення Концепції реалізації державної політики у сфері реформування загальної середньої освіти “Нова українська школа" на період до 2029 року : Розпорядження КМУ від 14 грудня 2016 р. № 988-p. 
16. Радзиевский АР, Верич ГЕ. Об оптимуме двигательной активности человека. Тези доп. IV міжнар. наук. конгр. [”Олімпійський спорт і спорт для всіх : проблеми здоров'я, рекреації, спортивної медицини та реабілітації’]. К. : Олімпійська література, 2000: 416.

17. Теорія і методика фізичного виховання. Т. 1. Загальні основи теорії і методики фізичного виховання. Під ред. Т. Ю. Круцевич, Київ: Олімпійська література, 2008. 392 с.

18. Теорія і методика фізичного виховання: підруч. для студ. вузів фіз. вихов. і спорту: у 2 т. За ред, Т.Ю. Круцевич. Т. 2: Методика фізичного виховання різних груп населення. К.: Олімпійська література, 2008. 367 c.

19. Худолій ОМ. Загальні основи теорії і методики фізичного виховання. Навч. посібник. 2-е вид., випр. Харків: “ОВС”, 2008. 406 с.: іл.

20. Шиян БМ. Теорія і методика фізичного виховання школярів. Частина 1. Тернопіль: Навчальна книга Богдан, 2001. 272 c.

21. Clements R. An investigation of the status of outdoor play. Contemporary Issues in Early Childhood. 2004; 5 (1): 68-80.

\section{References}

1. Bory'sova YuYu. Dy'ferencijovany'j pidxid u fizy'chnomu vy’xovanni shkolyariv na osnovi vy'kory'stannya komp'yuterny'x texnologij : avtoref. dy's. na zdob. nauk. stupenya kand. nauk z fiz. vy'x. i sportu : specz. 24.00.02 “Fizy'chna kul'tura, fizy'chne vy'xovannya rizny'x grup naselennya”. Dnipropetrovs'k, 2009. 20 s.

2. Vy'lenskaya TE. Fy'zy'cheskoe vospy'tany'e detej mladshego shkol'nogo vozrasta : ucheb. posoby'e. Rostov n/D: Feny'ks, 2006. 256 s.

3. Vil'chkovs'ky'j ES. Teoriya i metody'ka fizy'chnogo vy'xovannya ditej molodshogo shkil'nogo viku. L'viv: VNTL, 2008. $336 \mathrm{~s}$.

4. Volkov LV. Molodshy'j shkil'ny'j vik: vy'xovna spryamovanist' zanyat' fizy'chnoyu kul'turoyu i sportom : navch. posib. K.: Osvita Ukrayiny', 2007. 152 s.

5. Dy’namichni perervy'. 1-2 klasy'. uporyad. V. P. Poroshhuk. X.: Vy’d. grupa "Osnova”, 2018. 221, [3] s. (Seriya "Nova ukrayins'ka shkola").

6. Yedy’nak G. Plaxtij P, Yacenyuk Yu. Fizy’chna kul’tura v shkoli: molodomu specialistu : navch.-metod. posib. Kam'yanecz'-Podil., 2000. 305 s.

7. Krucevy'ch TYu. Bezverxnya GV. Rekreaciya u fizy'chnij kul'turi rizny’x grup naselennya : navchal'ny'j posibny'k. K.: Olimpijs'ka literatura, 2010. 248 s.

8. Krucevy'ch TYu. Petrovsky'j VV. Fy'zy'cheskoe vospy'tany'e kak socy'al'noe yavleny'e. Nauka v oly'mpy'jskom sporte. 2001; 3: 3-15.

9. Moskalenko NV. Fizy'chne vy'xovannya molodshy'x shkolyariv : monografiya D : Vy'd-vo "Innovaciya”, 2007. $252 \mathrm{~s}$.

10. Mudry’k SB. Ruxly'vi igry' na urokax fizy'chnoyi kul'tury' Lucz'k, 2008: 89 s.

11. Nova ukrayins'ka shkola: poradny'k dlya vchy’telya. Pid zag. red. Bibik N. M. K.: TOV “Vy’davny'chy'j dim "Pleyady", 2017: 24-25.

12. Ostrovecz' TO. Formuvannya moty'vaciyi do zanyat' fizy'chnoyu kul'turoyu shlyaxom zastosuvannya rizny'x zasobiv navchannya. Posibny'k dlya vchy'teliv fizy'chnoyi kul'tury', zdobuvachiv osvity' ZZSO, 2018. $21 \mathrm{~s}$.

13. Pro zatverdzhennya Derzhavnogo standartu pochatkovoyi osvity’: Postanova Kabinetu Ministriv Ukrayiny' vid 21 lyutogo 2018 r. № 87.

14. Pro sxvalennya Koncepciyi realizaciyi derzhavnoyi polity'ky' u sferi reformuvannya zagal'noyi seredn'oyi osvity' "Nova ukrayins'ka shkola" na period do 2029 roku : Rozporyadzhennya KMU vid 14 grudnya 2016 r. № 988-r.

15. Radzy'evsky'j AR, Very'ch GE. Ob opty’mume dvy'gatel'noj akty’vnosty' cheloveka. Tezy' dop. IV mizhnar. nauk. kongr. ['Olimpijs'ky'j sport i sport dlya vsix : problemy' zdorov'ya, rekreaciyi, sporty'vnoyi medy'cy'ny' ta reabilitaciyi']. K. : Olimpijs'ka literatura, 2000: 416.

16. Teoriya i metody'ka fizy'chnogo vy'xovannya. T. 1. Zagal'ni osnovy' teoriyi i metody'ky' fizy'chnogo vy’xovannya. Pid red. T. Yu. Krucevy'ch, Ky’yiv, Olimpijs'ka literatura, 2008, 392 s.

17. Teoriya i metody'ka fizy'chnogo vy'xovannya: pidruch. dlya stud. vuziv fiz. vy’xov. i sportu: V 2 t. Za red, T.Yu. Krucevy'ch. - T. 2. Metody'ka fizy'chnogo vy’xovannya rizny’x grup naselennya. K.: Olimpijs'ka literatura, 2008. $367 \mathrm{~s}$.

18. Xudolij OM. Zagal'ni osnovy' teoriyi i metody'ky' fizy'chnogo vy’xovannya. Navch. posibny'k 2-e vy'd., vy'pr. Xarkiv: "OVS", 2008. 406 s.: il.

19. Shy'yan BM. Teoriya i metody'ka fizy'chnogo vy'xovannya shkolyariv. Chasty'na 1. Ternopil': Navchal'na kny'ga Bogdan, 2001. 272 s. 
20. Clements R. An investigation of the status of outdoor play. Contemporary Issues in Early Childhood. 2004; 5(1): 68-80.

Цитування на цю статтю:

Кравченко ТП. Оптимізація фізичної підготовленості учнів молодшого шкільного віку засобами рухливих ігор в умовах нової української школи. Вісник Прикарпатського університету. Серія: Фізична культура. 2019 Берез 26; 33: 40-51

\begin{tabular}{l|l} 
Відомості про автора: & Information about the author: \\
\hline Кравченко Тетяна Петрівна - кандидат педагогіч- & Kravchenko Tetiana Petrivna - Candidate of Science \\
них наук, доцент, Переяслав-Хмельницький Дер- & (Education), Associate Professor (Ph. D.), Gregory \\
жавний педагогічний університет імені Григорія & Skovoroda Pereyaslav-Khmelnytsky State Pedagogical \\
Сковороди (Переяслав-Хмельницький Україна) & University (Pereyaslav-Khmelnytsky, Ukraina) \\
\hdashline e-mail: galenko-tanya @ rambler.ru & \\
https://orcid.org/0000-0002-6041-3101 & \\
\hline
\end{tabular}

УДК 378:796.8

doi: 10.15330/fcult.33.51-56

Едуард Лапковський, Ярослав Яців, Богдан Лісовський

\title{
ПРОГРАМА УДОСКОНАЛЕННЯ СПЕЦІАЛЬНОЇ ФІЗИЧНОЇ ПІДГОТОВКИ БОРЦІВ ВІЛЬНОГО СТИЛЮ ТА ЇЇ ВПЛИВ НА ЕФЕКТИВНІСТЬ ЗМАГАЛЬНОї ДІЯЛЬНОСТІ
}

\begin{abstract}
Мета. Теоретично обгрунтувати й розробити програму спеціальної фізичної підготовки бориів вільного стилю та перевірити ї̈ вплив на ефективність їх змагальної діяльності. Методи. У процесі виконання дослідження були застосовані аналіз наукової $і$ спеціальної літератури; педагогічне спостереження (вивчення результативності змагальної діяльності), педагогічний експеримент, методи математичної статистики. У педагогічному експерименті взяли участь 10 студентів-бориів вільного стилю у віиі від 18 до 20 років. Аналіз змагальної діяльності бориів проводили як безпосередньо в ході поєдинків, так $і$ в процесі перегляду відеозаписів. Визначали наступні показники змагальної діяльності: тривалість реальних атак, інтервали часу, через які поновлюються атаки, інтервал між успішними атаками, тривалість успішних атак, кількість отриманих балів, загальна тривалість сутички, кількість перемог та поразок. Результати. Для ефективного управління процесом розвитку швидкісносилових якостей студентів-спортсменів, які займаються вільною боротьбою було сформовано шість мікроциклів тренувань із використанням комбінацій вправ певного характеру впливу (розвиваючого фізично/технічно, контролюючого, підвідного, змагального, відновлювального). Особливість застосованої нами методики під час реалізаиії програми швидкісно-силового удосконалення бориів полягала в тому, щзо в період безпосередньої підготовки до змагань (за 21-28 днів) обсяг вправ із партнером досягав 70-80\%. Порівняння результативності змагальної діяльності до і після реалізації програми педагогічного експерименту дозволило встановити вірогідне збільшення часу реальних атак, зменшення інтервалу між атаками, зростання кількості успішних атак. Як наслідок, збільшилася кількість перемог на фоні сталого числа поразок. Висновок. Отже реалізація експериментальної програми удосконалення спеціальної фізичної підготовки бориів вільного стилю забезпечила покращення змагальної діяльності спортсменів, щзо підтверджено вірогідним зростанням тривалості реальних атак, зменшенням тривалості інтервалів між атаками, збільшенням кількості успішних атак та часу безпосередньої активної взаємодї з суперником. Як наслідок - зросла загальна кількість перемог на фоні незмінного числа поразок.
\end{abstract}

Ключові слова: борці вільного стилю, програма, спеціальна фізична підготовка, змагальна діяльність.

The purpose of the work was to evaluate the results of the competitive activity of the student-wrestlers after the application of the developed training program in the annual cycle. In the course of the research, the analysis of scientific and special literature was applied; pedagogical observation and experiment; pedagogical testing (studying the effectiveness of competitive activities), methods of mathematical statistics.

The analysis of the competitive activity of the student-wrestlers was conducted both directly during the matches, and in the process of video replay. The following indicators of the competitive activity of the student- 